\title{
Cecil B. DeMille and the Art ofApplied Suggestibility
}

\author{
By Anton Karl Kozlovic \\ Spring 2011 Issue of KINEMA \\ CECIL B. DE MILLE AND THE ART OF APPLIED SUGGESTIBILITY: VIOLENCE, SEX
AND FALSE MEMORIES WITHIN HIS BIBLICAL (AND OTHER) CINEMA
}

\begin{abstract}
Legendary producer-director Cecil B. DeMille is an unsung auteur who helped co-found both Hollywood and Paramount studios and became America's pre-eminent biblical filmmaker. He employed many artistic strategies, but none as politically astute as the deliberate engineering of false memories in a deliberate act of applied suggestibility. This trademark effort allowed DeMille to achieve desired audience reactions whilst simultaneously avoiding censorship problems and moral vigilantes who thought they saw objectionable things in his movies but which were not actually there. Consequently, selected DeMille films and the associated critical literature were inspected, reviewed and integrated into the text to enhance narrative coherence utilizing humanist film criticism as the guiding analytical lens. It was concluded that DeMille was a master filmmaker and that his cinematic oeuvre warrants a more thoughtful re-evaluation than evidenced to date. Further research into DeMille studies is therefore highly warranted, warmly recommended and already long overdue.
\end{abstract}

Introduction: The DeMillean Genesis of an Aesthetic Phenomenon

Producer-director $^{(1)}$ Cecil B. DeMille ${ }^{(2)}$ (1881-1959), affectionately known as "CB," was a seminal cofounder of Hollywood, a progenitor of Paramount studios, and an icon of American movies who pioneered numerous innovations in both the arts and sciences of the cinema throughout his seventy-feature film history (Birchard; Cherchi Usai and Codelli; DeMille and Hayne; Edwards; Essoe and Lee; Eyman; Higashi Guide, Culture; Higham; Koury; Louvish; Noerdlinger; Orrison; Ringgold and Bodeen). It is not certain exactly when DeMille first discovered the phenomenon of false memories and strategically deployed it as part of his engineered art of applied suggestibility, but his autobiography refers to it regarding the sexual impropriety scene involving Princess Verna (Elinor Fair) within his 1926 Russophile tale, The Volga Boatman:

The New York Telegram spoke of the "nice Lubitschean direction of a naughty scene where sensual faces register the successive stages in a suggested undressing of a princess". That scene caused a little difficulty with some censors. You must not, they said, show the undressing of the princess. But in fact we had not shown it. The story point of the scene is that the princess, protected from the revolutionaries by their leader, Feodor [William Boyd], is captured with him by the Imperial Army, whose commander gives his officers permission to "pay them in kind for what they do to our women" and only discovers, after the officers have begun to disport themselves with the princess, that she in fact is his fiancée. The scene is focused on the faces of the officers: the princess is not seen at all. But the acting and, if I may modestly say so, the direction must have been so good that some censors apparently thought they had witnessed an actual disrobing. (DeMille and Hayne 249) [my emphasis]

It remained a part of his storytelling arsenal because he deployed this very same suggestibility phenomenon at the other end of his career within his last directorial effort (and second Moses movie), but this time he was accused of excessive violence. As he reported in his autobiography:

I had a similar reaction when I screened The Ten Commandments (1956) for a large group of Methodist bishops. After the screening, the wife of one of the bishops said she had liked the picture very much, except for the part in which she had seen a Hebrew slave [Simon played by Francis J. McDonald] struck with an axe by an Egyptian overseer. There is no such scene in the picture. The bishop's wife had seen the overseer hurl the axe. She had seen the slave fall mortally wounded. Her imagination had supplied the intervening shot, which of course we would not put on the screen. As I have said before, the audience is an integral part of the total experience of a film; and good acting and direction always leave something for the audience to contribute to that experience. (DeMille and Hayne 249) [my emphasis] 
Not only was there a palpable absence of gore, violence and sex within DeMille's films due to the harsh censorial limitations of his day (and contrary to many people's perceptions-cum-expectations), but in some instances, DeMille was admonished for not presenting this trinity of decadence more vigorously to the eager paying public. For example, William Poster complained as follows about DeMille's muted portrayal of violence within his Technicolor testament, Samson and Delilah:

[Victor] Mature [playing Samson] is so soft and so little able to communicate the necessary sense of great bodily effort that even his pained romantic face and DeMille's elaborate system of distractions fail to maintain the central illusion. Indeed, the realization of physical violence and combat is so much below current Hollywood standards as to make one aware that DeMille's estimate of what is necessary for the creation of belief is based on silent films whose unlifelike rapidity of movement compelled audience reactions to remain within the frame of the cinema. DeMille no longer creates in the old terms and has not quite come to grips with the new.... (161-62) [my emphasis]

Not surprisingly, DeMille-the-cinematic-lay-preacher actively advocated selective perception regarding the screening of religious phenomena, particularly within his second Moses movie. In this instance, it was due less to the fretful concerns of censors and religious communities than to the technical difficulties in cinematically expressing the inexpressible, that is, of trying to make visually concrete what is essentially transcendental. As DeMille advised regarding Moses and the burning bush scene: "It is left to the viewer to grasp the meaning beyond the physical manner in which this revelation is materialized in The Ten Commandments" (Noerdlinger 24). This advice was in effect tacit acknowledgment of his resort to materialism to express spirituality on-screen, but it was also DeMille-the-authenticity-stickler's way of preemptively deflecting the inevitable public criticisms for even trying to depict the sacred (holy) with secular (mundane) means. It was an impossible task, but many critics wanted the impossible nonetheless, and despite the well-known limitations of cinematic art; let alone as a material medium of sacred expression.

For the purposes of this expository paper, selected films from DeMille's cinematic oeuvre and associated critical film, religion and DeMille literature were inspected, reviewed and integrated into the text to enhance narrative coherence (albeit, with a strong reportage flavour) utilizing humanist film criticism as the guiding analytical lens (i.e., examining the textual world inside the frame, but not the world outside the frame Bywater and Sobchack ch. 2). Many insights can be gleaned by exploring the interactions between the applied suggestibility phenomenon and Holy Scripture.

\section{Applied Suggestibility and Holy Scripture}

One of the many trade secrets that made DeMille "King of the epic Biblical spectacular" (Finler 32) was his trademark habit of engineering known scriptural phenomena into his films, which he learned from all the years he studied the Bible as a child, young man and adult. As his adversarial niece, Agnes de Mille claimed, Cecil had "a love of the Bible, a real deep one, and a profound understanding of it and a profound - Oh, he'd relied on this. He, he knew it by heart. That man knew his Bible" (Transcript, 2-4). As DeMille himself admitted near the end of his life, he had "studied it for seventy years" (Brigham Young University $5)$ and he elsewhere proudly claimed: "my ministry was making religious movies and getting more people to read the Bible than anyone else ever has" (Orrison 108).

Holy Writ is particularly notorious for its demonstrable lack of specific facts, physical descriptions or even situational contexts, thus forcing the reader to make interpretative leaps in a text-as-reader-construct fashion. Biblical scholar Athalya Brenner expressed this dilemma in the following way:

The physiognomy of figures-in-the-text is seldom if ever elaborated upon in the Bible. Minimal references, like the claim that a female or male figure are 'good-looking', can hardly satisfy our visual curiosity. Such absences set our imagination working. We plug the gaps, consciously or otherwise - as indeed we must, for these gaps and omissions are relevant to the act of reading. (231)

DeMille-the-Hollywood-lay-preacher also played with his audience's imagination in this plugging-the-gap fashion, especially as a biblical filmmaker who had to make implicit textual facts, audiovisually explicit (i.e., make tangible what is only implied). This filmmaking reality helps explain why some viewers were outraged 
at the gore, violence and sex they thought they saw in his films. However, it did not actually exist, rather, it was an imaginative projection of the viewers' own minds (albeit, deftly engineered by CB), but which the offended viewers nonetheless wanted to punish Cecil for!

DeMille-the-filmmaker was also being DeMille-the-astute-businessman by simultaneously balancing what the paying public wanted to see, avoiding censors and concerned church folk who wanted to stop (or compromise) his artistic vision, and yet still make enough profit for Paramount's purse to keep on working. As Bill van Dyk put it:

If you want to believe that Hollywood has set out to deliberately undermine the moral values of the country, you would have to demonstrate that Hollywood cares more about ideology than money, and that would [be] very difficult to prove. What most Christians really want are movies that show that Christians always end up happy and rich and sinners always end up unhappy and poor. This was the formula followed by Cecil B. De Mille, who had a lot of success with movies like "The Ten Commandments." Unfortunately, De Mille discovered that Christians - like everyone else - liked their movies to include some titillation - as long as the sinners were punished in the end. Thus he rather graphically illustrates the Israelites fall into paganism in the desert, before Moses Heston comes down the mountain with the stone tablets. We want propaganda for our side. We confuse propaganda with art. (online)

Similarly, many critics saw in DeMille's film what they wanted to see as opposed to what was actually there, thus unfairly distorting his cinema and reputation. For example, this selective perception phenomenon was dramatically self-evident within the review of Cecil's Samson and Delilah by William Poster, film critic for The Nation. The following is a brief critique of that film review.

William Poster's Critique of Samson and Delilah (1949)

Poster claimed that Cecil's Samson saga starring Victor Mature (as Samson) and Hedy Lamarr (as Delilah) had "a full DeMille complement of...half-clad women" (161) and that Samson "emerges as a superman whose magic strength functions without sweat, strain, or religion to amuse rather than awe the spectator" (161). However, a closer and more sympathetic inspection of the film reveals that these charges are untrue, and are well worth refuting herein to get a deeper insight into the phenomenon and DeMille's unfair treatment.

For a start, of the five major female protagonists, namely, Samson's mother, Hazeleponit (Fay Holden) and Delilah's personal servant, Hisham (Julia Faye) were both old and fully-clothed throughout the film, just as you would expect from mundane domestic women beyond the bloom of youth. Conversely, the two younger nubile beauties, Semadar (Angela Lansbury) and Delilah (Hedy Lamarr) could be expected to physically flaunt their bodies and beauty, however, DeMille had both of them fully clothed; sometimes wearing ornate two-piece outfits with an occasionally exposed shoulder blade or leg, but nothing more erotic, let alone dangerously pornographic to warrant the "half-clad" tag and its salacious implications (Kozlovic Babylon). In fact, in Semadar's intimate bedroom scene with her newly married Philistine husband, Ahtur (Henry Wilcoxon), she is wearing more clothes (albeit, flesh-coloured) whilst sitting on her nuptial bed than she wore at her own wedding party (i.e., the reverse behaviour of what you would expect from a bout of post-wedding passion)!

Furthermore, the small number of servant girls at that wedding party, the few Dagon dancing girls near the film's end, and the various female Philistine temple-gawkers watching the spectacle were all fully attired ranging from modest to opulent, and which literally covered most of their bodies. Miriam (Olive Deering), the virginal good-girl protagonist, and the plain-Jane Samson should have married was also modestly clad because she "had to look what any Jewish mother would choose for her son, practical, religious, unglamorous and marvellous about the house" (Lasky Jr. 221). This costuming reality had also visually confirmed Essoe and Lee's claim that DeMille "was always somewhat prudish in his treatment of women" (231). In short, there were no "half-clad women" (or nakedness) in Samson and Delilah. Poster is factually wrong.

Secondly, Samson did not display any "magical" strength within the film as Poster claimed; instead, DeMille depicted him as a physically strong man during his normal day-to-day life, such as effortlessly picking up his mother in her rustic kitchen. Samson's non-magical strength acts also involved determined-looking oneupmanship when he bent a metal spear before Semadar, Ahtur and a distantly-observing Delilah in Tubal's 
(William Farnum's) garden. Similarly, a hate-filled grimace accompanied Samson as he crushed a wine cup single-handedly before his astonished wedding guests following the unexpected loss of his bride-to-be, Semadar. This was all filmically upfront and self-evident. Even if one temporarily assumed that Poster's "magical" accusation is correct, it only served to verify the central feature of the Samson saga, namely, that Samson was an exceptionally strong man. DeMille had cinematically depicted this biblical fact accurately, so why criticize him for telling the scriptural truth? Rather than "magical" strength, DeMille depicted Samson displaying divinely-infused superhuman effort after praying to God. He did this twice, namely, when killing the Philistine soldiers with the jawbone of an ass (Judg. 15:16) ${ }^{(3)}$, and when toppling Dagon's statue and temple (Judg. 16:25-30). In short, Poster failed to differentiate between magic, divine infusion, and normal strongman powerfulness, but which was apparently DeMille's fault rather than Poster's lack of critical discernment.

Thirdly, whether God-infused or just extra-normally powerful, Samson's physical exertions frequently did result in "sweat, strain" (Poster 161) and related grimacing, which is self-evident throughout most of Samson and Delilah. For example, when Samson vigorously fought the young lion to its death (Judg. 14:5-6), and when he maniacally killed Ahtur's soldiers with the jawbone of an ass (Judg. 15:15-16), and even when he laboured painfully at the Philistine gristmill as a blind prisoner (Judg. 16:21) followed by the tension-filled collapsing of Dagon's temple and the subsequent crushing of the cruel Philistines who sported with him (Judg. 16:29-30). One cannot miss Samson's physical straining or sweating body during these dramatic renditions of established scriptural incidents, thus clearly belying Poster's claim that sweat and strain was not involved.

Fourthly, nor were DeMille's divinely-inspired divine strength acts crafted to "amuse rather than awe the spectator" (Poster 161), in fact, it was the precise reverse. Before Samson embarked upon the Philistinekilling spree at the Lehi pass, or the premeditated Dagon temple toppling mission, he earnestly prayed to God for holy support. On both occasions, his prayers were performed in tones designed to evoke the feelings of humility and righteous wrath, accompanied by holy musical signatures to verify the same. There was no laughter or frivolity from Samson on either of those devastating occasions. Furthermore, when there is major on-screen laughter and frivolity inside Dagon's temple, it is the scripturally accurate portrayal of loud-mouthed Philistines making sport of Samson (Judg. 16:25), and in a one-upmanship style of taunting by Samson's conquerors to rub in the fact of his defeat by a small, weak woman. Just like bullies and enemies are want to do everywhere; and especially against the strongest man in the world, which alone would justify their joviality and give both honor and praise to their god Dagon for defeating Yahweh's earthly ambassador.

Fifthly, the incredible devastations that followed Samson's two major Philistine-killing sprees were definitely not comic events, and they did inspire spectator awe, just as they inspired feelings of dread within his terrified on-screen victims. Interestingly, before both acts of cosmic one-upmanship, DeMille had Samson humorously mocked by dwarf antagonists in an act of "fun" versus "fear" binary plot construction. Even the use of dwarfs against Samson was a height-related act of "small" versus "big" binarism, as was the even greater height contrast between the dwarfs and the giant wrestler, Garmiskar (William Davis), both of whom used Samson as their intermediate focal point (physically and dramatically). Other structural binarisms occurred between the dwarf's freedom and Samson's chains, between their many weapons and Samson's weapon-less state, between their riotous fun and Samson's humiliating pain, whilst symbolically speaking, DeMille had depicted little people, belittling the belittled Samson. Overall, all of the above screen facts decries William Poster's critical comment and forces one to wonder what film he thought he was talking about, certainly not Samson and Delilah!

\section{Applied Suggestibility Born of Self-Censoring: DeMille as Czar Hays}

DeMille's confession of not putting certain scenes into his films (DeMille and Hayne 249) was in effect an admission of self-censoring, that is, the deliberate toning down of his infamous realism desires to accommodate the sensitivities of censors and audiences, who in truth could not handle the many gritty truths of biblical savagery, brutal sexuality and other perversions peppered throughout the Holy Scriptures. DeMille had realized this biblical fact early on in his career and argued: "I'm sometimes accused of gingering up the Bible with lavish infusions of sex and violence...but I wish that my accusers would read their Bibles more closely, for in those pages are more violence and sex than I could ever portray on the screen" (Essoe and Lee 195). He was absolutely right. A brief survey of that sacred text highlights incidents of Adultery (2 
Sam. 11:2-5), Bestiality (Lev. 18:23; 20:15-16), Cannibalism (2 Kings 6:28-29), Child Murder (Num. 31:17), Dismemberment (Judg. 19:26-29), Excretory Fun (2 Kings 18:27; Isa. 36:12), Foreskin Collecting (1 Sam. 18:25, 27), Homosexual Lusting (Rom. 1:26-27), Incest (Gen. 19:36), Necrophilia (Lev. 21:11), Pedophilia (Num. 31:17-18), Rape and Incest (2 Sam. 13:1-15), and Whoring (Judg. 16:1) (see Godawa Appendix for many more examples).

General audiences usually preferred their biblical ribbon-of-dreams spicy, but Sunday school sanitized, as hinted at by Bill van Dyk above. DeMille had passionately stated his self-censoring principle as follows:

If the dramatic construction of a story or its authenticity requires the portrayal of persons or scenes or situations which we might not relish having in our living-rooms, they should be portrayed as realistically as need be; and a writer or director worth his salt can portray them without offending either good morals or good taste. (DeMille and Hayne 273) [my emphasis]

Hence his frequent deployment of false memories via the applied suggestibility phenomenon; indeed, it appears that DeMille-the-prude also applied this sexual suggestibility-cum-self-censoring to his own family members and private life. As his niece, Agnes de Mille reported regarding her university graduation party that Cecil organized for her at his notorious Paradise ranch retreat:

No guest in the room was over twenty-two and our jewels were glass, but the faces above the Russian collars were burning with excitement. "And now, gentlemen," said Cecil to his barely bearded companions, "you will see what you have always longed to see." The boys looked at him questioningly. "Women quarrelling over jewels," he explained. The boys nodded sagely over their unfamiliar brandy snifters. A table of costume jewellery, French perfume, feather fans, powder compacts, and such was brought out by the houseboys, and the ladies - I and my schoolmates were given dice to roll for first choice. When this was over (and I don't recall that we scrapped unduly for the goodies), we went out into the night feeling somehow that we had lifted the curtain an inch or two on debauchery and Roman splendour. Somewhat later, but at an early hour, Cecil policed the houses to see that we were all stowed away exactly as we should be. I was sitting decorously by the pool in the moonlight with my boyfriend, not even holding hands. We were politely but firmly escorted by my uncle with a flashlight to our separate houses. Debauchery over. (181-82)

So much for DeMille's salacious reputation at this particular time, place and situation.

\section{DeMille, the Critics and Academia}

This seeing-what-you-want-to-see phenomenon also worked against DeMille on occasion. He once annoyingly stated, and then quickly compensated for, by reporting:

...I think one may be forgiven an ever so slight allergic reaction when all that effort and skill on a picture like Samson and Delilah are airily summed up, even by a friendly critic, as "the most expensive haircut in history". People see in any motion picture only what they have eyes to see. The young Presbyterian minister in East Grand Forks, Minnesota, who wrote to me, "I trust my ministry will be more according to God's will for having seen Samson and Delilah," told me as much about himself in those words as he did about the picture. (DeMille and Hayne 367-68) [my emphasis]

DeMille also referred to the principles of the suggestibility phenomenon regarding The Ten Commandments (1956) when he said: "He will see what he has eyes to see" (DeMille and Hayne 382), and again script-wise when the feeble old Story Teller (Francis J. McDonald) at the beginning of Samson and Delilah counselled the dangerously enthusiastic young Saul (Russell Tamblyn) with: "Some thoughts must not be spoken." When Samson said to the disbelieving Saran of Gaza (George Sanders) regarding his barehanded lion-killing efforts (enthusiastically recounted by Delilah): "The girl told you the truth. What you believe is your affair." This retort could well have been DeMille's motto for the suggestibility phenomenon.

Somewhat intriguingly, this phenomenon also had its counterpart in the academic domain. Gina Marchetti noted how DeMille's masterpiece The Cheat was one of "the most notable silent feature films dealing with interracial rape...rape and the possibility of lynching" (10), but later on she admitted that: "no actual rape or 
lynching is depicted in The Cheat" (16), and then proceeded to explore the film's role in the public discourse surrounding rapes and lynchings as if DeMille were its exemplar extraordinaire! Where Marchetti derived her academic warrant to colour DeMille's reputation in this way (as opposed to corrective elucidation) was not justified; only assumed.

Nor was this the only regrettable incident of erroneous DeMille-related academic projection. Cullen Murphy referred to a biblical conference entitled: "Women Who Kill" that had used a video clip from Samson and Delilah to showcase the conference theme. Temporarily overlooking the fact that Delilah (whether in the Bible or DeMille's on-screen rendition) did not want to kill Samson, was not charged with a mission to kill Samson, and did not kill Samson, Murphy reported that:

One person saw the Samson and Delilah story as centering psychologically not on Delilah's deceit but on the (presumably) male authors' fears of castration. The suggestion is not implausible. Hair has famously erotic overtones, and the dangling knot that Hedy Lamarr [Delilah] slices from Samson [Victor Mature] - and here the video clip served as a triumphant visual aid - embodies them unmistakably. (111)

Therefore, for these two academics, Delilah really had Samson by the symbolic balls. Admittedly, this reading may have made DeMille proud as it had accurately captured the quintessential features of both the scriptural incident and Cecil's rendition of it without invoking the wrath of censors, moral vigilantes or other potentially fulminating fanatics.

Furthermore, the suggestibility phenomenon was skilfully deployed here yet again because Delilah did not physically cut Samson's hair on-screen in strict accordance with Holy Writ (as opposed to popular belief) which clearly stated that Delilah "called for a man, and she caused him to shave off the seven locks of his [Samson's] head" (Judg. 16:19) [my emphasis]. DeMille-the-harmonizer balanced the Scriptures and popular perception by depicting Delilah indoors playing with the hair of the drugged Samson then drawing his knife and slowly approaching his hair with it as if she was going to cut it, then making a sudden jump cut to a beautiful sunrise scene followed by another jump cut to an indoor scene of an awakening shorn Samson next to Delilah and a bowl containing his cut curls. Once again, DeMille let the audience fill in the gap of Delilah physically cutting Samson's hair whereas, theoretically speaking, she could have called in a barber off-screen between her hair-fondling and the shorn Samson waking up.

\section{Sex in the (Ancient) City}

In addition to being the master of applied suggestibility, DeMille was also the master of the art of sexless sex, as evidenced in Samson and Delilah (Kozlovic Babylon), and also in the royal barge scene within his Egyptian biopic, Cleopatra. This ancient epic had Marc Anthony (Henry Wilcoxon) and Cleopatra (Claudette Colbert) suggestively "merge" together behind silken curtains "so that we can't see what's going on. But imagine goings-on taking place with only a curtain separating the going-oners from the gallery!" (Rob Wagner qtd. in Slide 51). Classics scholar Maria Wyke referred to this incident as follows:

Through the use of DeMille's visual system of objective correlatives, Anthony is represented as engulfed and unmanned by a woman's body in the sequence where the Roman visits Cleopatra's barge at Tarsus. When Anthony enters the feminine ship, he passes between a double line of women waving soft fans to reach within a Cleopatra who reclines before a vulvaic mass of plumes. On the way to being sexually possessed by the queen - a "gorgeous piece of cinematic euphemism" involving the rhythmic thrusting and retracting of her ship's banks of oars - Anthony loses all the emblems of his Roman virility, namely his soldier's helmet, his huge wolfhounds, and his upright stance. (96)

DeMille's deployment of fan plumes as sexual symbols would have done Busby Berkeley proud; indeed, they frequently engineered each other's style into their own films because of their competitive admiration for each other (Rubin 41-42).

Given that DeMille was not allowed by the censorial authorities and moral vigilantes of his day to display floppy breasts, bare bums, pubic triangles or gyrating pneumatics, he had to resort to sexual suggestiveness through audiovisual metaphors. For example, in Samson and Delilah, the youthful Delilah was infatuated with Samson though she plainly knew that Samson was in love with and intended to marry her older sister, 
Semadar. Consequently, at the wedding feast, DeMille resorted to overt sexual suggestiveness coupled with covert sexual suggestiveness. Whilst the adversarial Philistine guests were pondering the answer to Samson's unbeatable neck-riddle, the coquettish Semadar (whom biblical scholar James Crenshaw imagined as a "ravishing beauty" (77) although scripturally unsupported) momentarily stopped before leaving the party with Samson. She then mockingly advised her puzzled guests to: "Find the answer before the wedding, Samson will have no time for riddles afterwards." This comment was pregnant with anticipatory sexual knowing, as also indicated by the equally knowing groans of delight from the titillated wedding guests.

In doing so, DeMille had invoked the suggestibility phenomenon by indirectly inviting the audience to reflect upon their own wedding night antics and/or other intimate couplings. In short, it was sex-by-association that would not get DeMille into trouble with the censors and the church folk, nor could he be accused of hypocrisy when he claimed to his financiers when pitching this beard-and-bathrobe project: "We'll sell it as a story of faith, the story of the power of prayer. That's for the censors and the women's organizations. For the public it's the hottest love story of all time" (Koury 206).

Indeed, for Elizabeth Wurtzel, the biblical Samson saga is "the story of sexy stories...always an entertaining and sacred scandal sheet" (38), and which DeMille had accurately portrayed on-screen because it was scripturally true and not just an obsession of DeMille-the-salacious-cineaste. As Scripture scholar J. Clinton McCann put it:

The last and probably best known of the judges is Samson, although most people's knowledge of Samson is limited to his relationship with Delilah (16:4-31); and the source of people's knowledge is as likely to be Cecil B. DeMille's film Samson and Delilah as it is the biblical text. Samson's story contains all the features that make for a top-rated movie - excessive violence, romance and sex, and R-rated humor. No wonder it attracted DeMille! (92)

Seeing-what-you-want-to-see projection was also frequently evident by Scripture scholars in addition to academics and critics. For example, the Bible referred to "thirty companions" (Judg. 14:11) accompanying Samson at his wedding feast, and later these companions were referred to as "the men of the city" (Judg. 14:18), thereby implying maturity. Therefore, DeMille's wedding guests were many, mature, and mainly bearded men-of-the-world, and yet, biblical scholar Mieke Bal perceived these companions to be unmarried youth who were sexually innocent and immature. As she argued:

...the fact that Samson asks the riddle of bachelors, the night before his own wedding, could symbolize his claim to be, as a groom, better informed in sexual matters than his virginal companions. The young men don't know the answer: they are not mature yet. Their only resource is the [Timnath] woman [Judg. 14:1; DeMille's Semadar]. They threaten her into betraying her groom's secret. (43) [my emphasis]

Thus highlighting once again that DeMille was sometimes far more accurate in his cinematic rendition of Holy Writ compared to contemporary biblical scholars, and that such scholars are not immune from projecting their own personal preoccupations into textual gaps.

Indeed, Samson's supposedly undecipherable lion-and-honey riddle: "Out of the eater came forth meat, and out of the strong came forth sweetness" (Judg. 14:14), which DeMille reproduced almost word for word, is itself an example of a potential oral sex double entendre. This interpretation is entirely appropriate under the circumstances according to Samson scholar James Crenshaw who suggested that:

On another level, the riddle suggests copulation. Such erotic thoughts naturally accompanied wedding festivities, and consequently posed the biggest snare for the Philistines. A veiled allusion to the sex act, the riddle uses the cipher "eater" and "strong one" for the groom. Similarly, "food" and "sweetness" signify semen, which is sweet to the bride who "eats" the sperm. From man proceeds sperm which nourish woman; from a strong man goes semen that is pleasant to a wife.

However, this semen-sweetness interpretation can also refer to sexual enjoyment if interpreted more broadly, as Hebrew scholar James D. Martin did when he argued that: "To the Philistines, the strong might have been thought to refer to Samson's virility and sexual prowess" (166). But if interpreted more narrowly, then 
it might refer to sexual intercourse per se and not oral sex because as sexologist David Delvin informed: "semen has a slightly salty and slightly bitter taste" (135) whilst the penis itself "has an attractive but not particularly strong taste, usually with a tangy or slightly musky flavour" (118). Therefore, talk of eating sweetness can be physically misleading.

Even the biblical answer to Samson's riddle: "What is sweeter than honey? and what is stronger than a lion?" (Judg. 14:18), which DeMille reproduced via Ahtur as: "What is sweeter than honey Samson?...Tell us! What is stronger than a lion?" is itself full of sexual promise. Why? Because: "'What is sweetest and strongest?" alludes to love's power and ecstasy" (Crenshaw 117), all of which had gone very sour for Samson when he was betrayed by his Philistine wife-to-be, lost his unbeatable riddle wager, and eventually lost his freedom, eyesight and ultimately his life in Dagon's toppled temple. To reinforce the emotional impact of Samson's lost riddle wager linked to sexual cuckolding, DeMille had one unseen Philistine wedding guest say: "Ahtur won the Danite's wager" which was quickly cut off by a second unseen guest who chimed in with "or the Danite's bride!" This cheeky retort was followed by raucous crowd laughter that further intensified the ethnic insult, aggravated Samson's public humiliation, and grossly wounded his personal pride that eventually led to his multiple murder of men (Judg. 14:19) and further anti-Philistine atrocities thereafter (Judg. 15:15; 16:27, 30).

\section{Applied Suggestibility and DeMille's Hidden Social Engineering Agenda}

DeMille also resorted to hidden messages and suggestibility tactics in his Oscar-winning circus film, The Greatest Show on Earth; a subtle variety of which was explored regarding the thorny issue of euthanasia in 1950s America. James Stewart played Buttons-the-clown who never took off his makeup during the entire film. It was subsequently revealed that he was wanted for murder because as a former medical doctor he had helped his wife to die. Since the police were pursuing him, he took refuge in the circus and hid behind his stage makeup before another act of medical compassion exposed his true identity to the police. The medical, ethical or legal words to describe euthanasia were not mentioned on-screen; however, film critics and commentators frequently interpreted this "murder" as an act of "mercy killing" (Black 117; Quirk 209) or "euthanasia" (Heston and Isbouts 40; Quigley Jr. and Gertner 211). It was an inference unsupported by inspection of the on-screen data but supplied by the commentators, if not extra-cinematically, then via a suggestibility pathway.

The original film script was more open and honest about DeMille's intent, but which had prompted the displeasure of the censorial authorities of the day. As Gregory D. Black reported, the mercy-killing gravely concerned the Legion of Decency because they feared that young people "might carry away the notion that this act...could not have been so bad or that nice clown would not have done it" (117). Was DeMille trying to exert a form of ideological infiltration by sugar-coating this hard-to-swallow euthanasia pill (especially by anti-interventionist Catholics) by hiding it behind a fun-loving character such as a clown? And especially with the perpetrator being a respectable person from a respectable profession behind that clown face who was depicted throughout the film as being upright, honourable and compassionate. Was DeMille hiding behind a fun-loving genre like the circus film to teach moral lessons and subtly suggest that euthanasia was not so bad or wrong; and especially in an Oscar-winning feature made straight after Samson and Delilah that had showcased God sanctioning (or at least not stopping) Samson committing a very deliberate act of suicide? Indeed, Samson was a very committed suicidal terrorist (Wicker) who had reeked vengeance upon the Philistines for the lost of his eye sight, coupled with him earnestly praying to God to give him back his phenomenal strength to do it (Judg. 16:28).

The writer suspects that DeMille may have trail-blazed this particular social cause because of the growing dementia of his much-loved elderly wife, Constance, who was somewhat senile before Cecil's death (Higham 312-13), coupled with James Stewart wanting to act in a DeMille film simply because CB was an industry legend and his professional association was good for his career (Fishgall 226-27). Furthermore, this DeMillean attempt at social engineering was not a once-off affair for he frequently explored serious social issues throughout his career. For example, he dealt with Marriage Haste in Old Wives For New, Unrequited Love in We Can't Have Everything, Traitorous Partners in Till I Come Back to You, Slovenly Partners in Don't Change Your Husband, Honor in Marriage in For Better, For Worse, Incompatible Partners in Why Change Your Wife?, Suicide in Feet of Clay, Reincarnation and Soul Travel in The Road to Yesterday; and Birth Control in Four Frightened People "the only occasion we know in which this subject is treated in a 
Hollywood movie" (King 97) or as Robert S. Birchard put it: "Who but DeMille would give audiences a Pekinese-toting feminist lecturing South Sea natives on the liberating rewards of birth control" (267). A thorough examination of the rest of DeMille's filmic oeuvre will reveal other socially relevant concerns deftly ensconced therein.

As DeMille-the-Christian and DeMille-the-people's director he was always attentive to the public's wants which he used as the inspirational basis for his filmic fare, thus resulting in "the typical DeMille formula; sin, sex, and titillation - but in the end, adherence to an absolute moral code" (Dixon and Foster 42). This filmmaking praxis partially explains why he frequently infused implications of sex into his work; forever tagging himself as a sex-and-sin merchant, but which was very tame in its day and next to nothing compared to today's neo-pornographic offerings. Indeed, while making his first The Ten Commandments and The King of Kings, DeMille had sensed a basic duality in audiences between sinful taboo and righteous respectability that he incorporated into many of his films as an act of social mirroring (which itself ensured box office success for DeMille-the-businessman). It was not a raw reflection of DeMille's allegedly fallen nature or prurient desires, but rather, evidence of his professional decision to be a tasteful salacious cineaste for commercial reasons as a servant of the masses who had faithfully adhered to his own dictum: "The Public is Always Right!" (Naughton and Smith 20). Unfortunately, many critics could not always surmount their anti-DeMille biases and so confused the mirror with the man.

\section{Conclusion}

Utilizing the art of applied suggestibility was a key filmmaking trademark and auteur signature sign of "Hollywood's best known unknown" (Arthur 283). DeMille certainly deserves full credit as a popular cinematic artist who employed innovative storytelling techniques and explored numerous socio-cultural issues for audiences to mull over whilst enjoying themselves at America's foremost fun factory. However, there are even greater layers of depth and meaning within DeMille's films than initially meets the eye or has been acknowledged by critics, commentators and academics to date. Rather than indifference, DeMille's entire filmic career, reputation and rightful place within both Hollywood history and American popular culture warrants a more thoughtful re-examination of his life, films and career. As such, further research into DeMille studies is highly warranted, warmly recommended and already long overdue; after all, it was not without good reason that DeMille was applauded as "a master of the film narrative" (Gomery 80).

\section{Notes}

1. DeMille was so complex and multi-faceted that to describe, let alone justify each aspect would be prohibitive; therefore, concise, hyphenated compound terms will be used throughout to disentangle his complexity and avoid needless explanation, justification or reader boredom.

2. Many commentators have spelled Cecil's surname as "De Mille" or "de Mille" or "deMille" however, the correct professional spelling is "DeMille" (DeMille and Hayne 6), which will be used herein (unless quoting) alongside "Cecil" and "CB" as appropriate.

3. The Authorized King James Version of the Bible (KJV aka AV) will be used throughout (unless quoting other translations) as it was frequently used by DeMille (Higashi 1994, 180), and because most of the biblical phrases that are embedded in Western culture come from this widely used translation (Taylor 1992, ix, 71).

\section{References}

\section{Works Cited}

Arthur, Art. "DeMille: Man and Myth." DeMille: The Man and His Pictures. Eds. Gabe Essoe and Raymond Lee. New York: Castle Books, 1970. 283-88.

Bal, Mieke. Lethal Love: Feminist Literary Readings of Biblical Love Stories. Bloomington: Indiana UP, 1987.

Birchard, Robert S. Cecil B. DeMille's Hollywood. Lexington: UP of Kentucky, 2004. 
Black, Gregory D. The Catholic Crusade against the Movies, 1940-1975. Cambridge: Cambridge UP, 1988. Brenner, Athalya. "Afterword." A Feminist Companion to Judges. Ed. Athalya Brenner. Sheffield: Sheffield Academic P, 1993. 231-35.

Brigham Young University, MSS 1400, CBD, Box 221, Folder 6, Cecil B. DeMille - Student Editors' Interview, New York, Reel 1, 5, 21 February 1958.

Bywater, Tim, and Thomas Sobchack. An Introduction to Film Criticism: Major Critical Approaches to Narrative Film. New York: Longman, 1989.

Cherchi Usai, Paolo and Lorenzo Codelli, eds. The DeMille Legacy. Pordenone: Le Giornate del Cinema Muto/Edizioni Biblioteca dell'Immagine, 1991.

Crenshaw, James L. Samson: A Secret Betrayed, a Vow Ignored. Atlanta: John Knox P, 1978.

Delvin, David. Love Play: Over 100 Foreplay Techniques for a Happy and Fulfilled Sex Life. Sydney: Angus \& Robinson, 1994.

de Mille, Agnes. Portrait Gallery. Boston: Houghton Mifflin, 1990.

Interview Transcript, Timeline Films DeMille Documentary, Tape 2/-4, December 25, 1997.

DeMille, Cecil B., and Donald Hayne, ed. The Autobiography of Cecil B. DeMille. London: W. H. Allen, 1960 .

Dixon, Wheeler W., and Gwendolyn A. Foster. A Short History of Film. New Brunswick: Rutgers UP, 2008.

Dyk, Bill van. "Christ at the Movies: Some Random Thoughts about Christianity and Culture in the 1990s." http://www.chromehorse.net/movies/menus/christ.htm. Online: June 1, 2010.

Edwards, Anne. The DeMilles: An American Family. London: Collins, 1988.

Essoe, Gabe, and Raymond Lee. DeMille: The Man and His Pictures. New York: Castle Books, 1970.

Eyman, Scott. Empire of Dreams: The Epic Life of Cecil B. DeMille. New York: Simon \& Schuster, 2010.

Finler, Joel W. The Movie Directors Story. London: Octopus Books, 1985.

Fishgall, Gary. Pieces of Time: The Biography of James Stewart. New York, NY: Lisa Drew/Scribner, 1997.

Godawa, Brian. Hollywood Worldviews: Watching Films with Wisdom $\mathcal{E}$ Discernment. Downers Grove, IL: InterVarsity P, 2002.

Gomery, Douglas. Movie History: A Survey. Belmont, CA: Wadsworth, 1991.

Heston, Charlton, and Jean-Pierre Isbouts. Charlton Heston's Hollywood: 50 Years in American Film. New York: G T Publishing, 1998.

Higashi, Sumiko. Cecil B. DeMille: A Guide to References and Resources. Boston, MA: G. K. Hall \& Co, 1985 .

. Cecil B. DeMille and American Culture: The Silent Era. Berkeley: U of California P, 1994.

Higham, Charles. Cecil B. DeMille. New York: Charles Scribner's Sons, 1973.

King, Carl. The Best Show in Town. Wyong, NSW: Reid's Film Index, npd.

Koury, Phil A. Yes, Mr. De Mille. New York: Putnam, 1959.

Kozlovic, Anton K. "The Whore of Babylon, Suggestibility, and the Art of Sexless Sex in Cecil B. DeMille's Samson and Delilah (1949)." Sex, Religion, Media. Ed. Dane S. Claussen. Lanham, MD: Rowman \& Littlefield, 2002. 21-31.

Lasky Jr., Jesse L. Whatever Happened to Hollywood? London: W. H. Allen, 1973.

Louvish, Simon 2008: Cecil B. DeMille: A Life in Art. New York: Thomas Dunne Books/St. Martin's P. 
Marchetti, Gina. Romance and the "Yellow Peril": Race, Sex, and Discursive Strategies in Hollywood Fiction. Berkeley: U of California P, 1993.

Martin, James D. The Book of Judges. Cambridge: Cambridge UP, 1975.

McCann, J. Clinton. Judges. Louisville, KY: John Knox P, 2002.

Murphy, Cullen. The Word According to Eve: Women and the Bible in Ancient Times and Our Own. London: Allen Lane/The Penguin P, 1999.

Naughton, John, and Adam Smith. Movies: A Crash Course. London: Simon \& Schuster, 1998.

Noerdlinger, Henry S. Moses and Egypt: The Documentation to the Motion Picture The Ten Commandments. Los Angeles: U of Southern California P, 1956.

Orrison, Katherine. Written in Stone: Making Cecil B. DeMille's epic, The Ten Commandments. Lanham: Vestal P, 1999.

Poster, William. "Films." The Nation 170.7 (1950): 161-62.

Quigley Jr., Martin and Richard Gertner. Films in America 1929-1969. New York: Golden P, 1970.

Quirk, Lawrence J. James Stewart: Behind the Scenes of a Wonderful Life. New York: Applause, 1997.

Ringgold, Gene, and DeWitt Bodeen. The Complete Films of Cecil B. DeMille. Secaucus, NJ: The Citadel $\mathrm{P}, 1969$.

Rubin, Martin. Showstoppers: Busby Berkeley and the Tradition of Spectacle. New York: Columbia UP, 1993.

Slide, Anthony, ed. Selected Film Criticism 1931-1940. Metuchen, NJ: The Scarecrow P, 1982.

Taylor, Mark D. The Complete Book of Bible Literacy, Wheaton, IL: Tyndale, 1992.

Wicker, Brian. "Samson Terroristes: A Theological Reflection on Suicidal Terrorism." New Blackfriars 84.983 (2003): 42-60.

Wurtzel, Elizabeth. Bitch: In Praise of Difficult Women. New York: Doubleday, 1998.

Wyke, Maria. Projecting the Past: Ancient Rome, Cinema, and History. New York: Routledge, 1997.

\section{Filmography}

Cleopatra (1934, dir. Cecil B. DeMille)

Don't Change Your Husband (1919, dir. Cecil B. DeMille)

Feet of Clay (1924, dir. Cecil B. DeMille)

For Better, For Worse (1919, dir. Cecil B. DeMille)

Four Frightened People (1934, dir. Cecil B. DeMille)

Old Wives For New (1918, dir. Cecil B. DeMille)

Samson and Delilah (1949, dir. Cecil B. DeMille)

The Cheat (1915, dir. Cecil B. DeMille)

The Greatest Show on Earth (1952, dir. Cecil B. DeMille)

The King of Kings (1927, dir. Cecil B. DeMille)

The Road to Yesterday (1925, dir. Cecil B. DeMille)

The Ten Commandments (1923, dir. Cecil B. DeMille)

The Ten Commandments (1956, dir. Cecil B. DeMille) 
The Volga Boatman (1926, dir. Cecil B. DeMille)

Till I Come Back to You (1918, dir. Cecil B. DeMille)

We Can't Have Everything (1918, dir. Cecil B. DeMille)

Why Change Your Wife? (1920, dir. Cecil B. DeMille)

\section{Author Information}

Anton Karl KOZLOVIC (PhD Flinders) researches in the Screen Studies department, School of Humanities at Flinders University (Adelaide, Australia). His interests include religion-and-film, computer films, and the biblical cinema of Cecil B. DeMille. He has published in journals including Australian Religion Studies Review, Belphegor: Popular Literature and Media Culture, The Film Journal, Journal of Contemporary Religion, The Journal of Religion and Film. 